\title{
Prelinguistic Communicative Factors Discriminating between Developmental Language Delay and Typical Language Development at 2 Years in Preterm Toddlers
}

\author{
HyoJoo Lee ${ }^{\mathrm{a}}$, YoonKyoung Lee ${ }^{\mathrm{b}}$ \\ aDepartment of Speech-Language Pathology and Audiology, Graduate School of Hallym University, Chuncheon, Korea \\ ${ }^{b}$ Division of Speech Pathology and Audiology, Hallym University, Chuncheon, Korea
}

Correspondence: YoonKyoung Lee, $\mathrm{PhD}$ Division of Speech Pathology and Audiology, Hallym University, 1 Hallimdaehak-gil,

Chunchon 24252, Korea

Tel: $+82-33-248-2219$

Fax: +82-33-256-3420

E-mail: ylee@hallym.ac.kr

Received: July 5, 2016

Revised: August 16, 2016

Accepted: August 20, 2016

This work was supported by the National Research Foundation of Korea Grant funded by the Korean Government (NRF-2014S1A5A2A01015713).

This article is an excerpt from the PhD's thesis of the first author (2016).

\begin{abstract}
Objectives: Prelinguistic communicative behaviors are important discriminating factors discriminating language delay from typical development. The purpose of this study was to examine the prelinguistic communicative behavior that most effectively distinguish the DLD from TD at 2 years in preterm toddlers. Methods: The participants were 47 preterm toddlers with a first evaluation at 15 to 18 months and a second at 24 months. Based on the assessment results, the participants were classified into 3 groups: 'typical- typical', 'delay-typical', and 'delay-delay'. The frequency and type of intentional communicative behavior, the frequency and type of gestures, the frequency of vocalizations, and the types of consonants were measured from the behavior samples that were collected during freeplay with caregiver. Discriminant analysis was conducted for identifying factors to discriminate between DLD and TD. Results: The 'delay-delay' group showed a significantly lower frequency of intentional communicative behavior, gestures, vocalizations, and a lower number of consonants. The results of discriminant analysis indicated that the frequency of gestures and intentional communicative behavior, the types of consonants were most significant to discriminate the subsequent presence of language delay in preterm toddlers. Conclusion: We discuss the prelinguistic communication factors for distinguish the DLD group from TD in preterm toddlers based on these results.
\end{abstract}

Keywords: Preterm toddler, Prelinguistic communicative factor, Discriminant analysis
미숙아로 출생한 영유아들은 언어 및 의사소통 발달 측면에서 만삭아로 출생한 영유아들보다 느린 발달을 보인다는 연구결과들 이 많이 보고되어 왔다(Aram, Hack, Hawkins, Weissman, \& Borawski-Clark, 1991; Foster-Cohen, Edgin, Champion, \& Woodward, 2007; Koldewijn et al., 2009; Schults, Tulviste, \& Haan, 2013; Stolt et al., 2014a; Vohr, 2014). 국내 언어병리학 분야에서는 최근 미 숙아 집단의 언어 및 의사소통 행동에 대하여 소수의 연구자들이 사회적 의사소통 행동과(Lee \& Lee, 2014), 언어발달지체 출현율을 살펴보았으나(Lee \& Lee, 2016), 비교적 활발하지 않은 실정이다. 반
면, 해외에서 발표된 미숙아 집단의 언어 및 의사소통 행동의 연구 동향을 살펴본 Lee와 Lee (2013)는 분석한 총 30편의 연구 중 20편 의 연구가 영유아를 대상으로 진행되었고, 이 중 16 편의 연구에서 미숙아 집단이 만삭아 집단과 언어 및 의사소통 행동발달에서 차 이를 보이는 것으로 나타났다. 미숙아로 출생한 영유아들은 초기 언어이전기 의사소통 행동(De Schuymer, De Groote, Beyers, Striano, \& Roeyers, 2011; Lee \& Lee, 2014), 몸짓 사용(Sansavini et al., 2011), 발성 산출(De Groote, Roeyers, \& Warreyn, 2006; Oller, Eilers, Steffens, Lynch, \& Urbano, 1994), 수용 및 표현언어 능력(Born- 
stein \& Haynes, 1998; Soraya, Mahmoodi-Bakhtiari, Badiee, Kazemi, \& Soleimani, 2012; Van Noort-Van Der Spek, Franken, Wieringa, \& Weisglas-Kuperus, 2010) 등에서 취약한 특성을 보인다.

미숙아로 출생한 영유아의 언어발달지체는 연령이 증가되어도 유지되는 경우가 상대적으로 높지만, 일부 영유아들은 연령이 증 가됨에 따라 뒤늦게 정상발달수준에 도달하기도 한다(Cattani et al., 2010; Marston, Peacock, Calvert, Greenough, \& Marlow, 2007; Saavalainen et al., 2006). 미숙아로 출생한 영유아의 언어이전기 의 사소통 행동과 이후 언어발달을 살펴본 Cattani 등(2010)의 연구에 따르면 12-21개월 사이에는 미숙아 집단의 언어 및 의사소통 행동 발달이 만삭아 집단과 유의한 차이를 보였으나, 24 개월에는 집단 간 유의한 차이를 보이지 않았다. 이에 미숙아로 출생한 영유아가 초기에 보인 언어발달지체가 정상언어발달 수준을 따라 잡을지, 아니면 지속적으로 지체를 보이는지에 대해 이른 시기에 확인하는 것이 매우 중요할 것이다.

영유아의 언어발달지체에 대한 조기 발견과 중재는 그 시기가 이 를수록 더 긍정적인 효과를 가져다준다. 무엇보다 지체나 장애를 가급적 빨리 발견하여 중재를 제공한다면 이후 발생 가능한 문제 를 더 효과적으로 예방할 수 있을 것이다(Moeller, 2000; Rossetti, 2001; Snow \& McGaha, 2003). 출생부터 형성된 위험요인(established risk factors)을 가지고 태어난 영유아는 조기 발견과 진단 시 기가 비교적 빠를 수 있지만, 그 외 발달위험요인(at-risk factors)을 가진 경우에는 조기 발견과 중재의 필요성에 대한 결정을 내리기가 쉽지 않기 때문에 다른 영역의 발달적 어려움 없이 언어발달에서만 지체를 보이는 영유아에 대한 진단은 2 세가 될 때까지 기다리는 경 우가 많다(Rescorla \& Schwartz, 1990).

많은 연구자들은 초기에 언어발달지체를 보였지만 이후 정상언 어발달수준에 도달하는 영유아와 지속적으로 언어발달지체를 보 인 영유아를 조기에 구별해주기 위한 요인으로 의사소통 행동의 표현 빈도, 의사소통 행동의 유형수, 몸짓 사용, 발성 산출, 자음 포 함 발성 산출과 같은 초기 의사소통 행동을 살펴보았다(Cho \& Lee, 2010; Hong, 2004; Jeon, 2014; Jeon \& Lee, 2015; Jeon, Lee, \& Lee, 2013; Thal \& Tobias, 1992; Wetherby, Yonclas, \& Bryan, 1989). 언 어이전기 의사소통 행동은 언어발달과 밀접한 관련을 보이며, 이후 언어발달 정도를 반영하기 때문에(Hong, 2004; Thal \& Tobias, 1992; Wetherby et al., 1989) 미숙아로 출생한 영유아들의 언어이전기 의 사소통 행동의 패턴을 확인하는 것이 필요할 것이다. 즉, 미숙아 집 단 내에서 정상언어발달 집단과 언어발달지체 집단을 조기에 구별 하기 위한 요인으로 언어이전기 의사소통 행동을 살펴본다면, 미숙 아로 출생한 영유아의 이후 언어발달과 관련된 조기 평가와 중재에
대한 중요한 정보를 제공할 수 있을 것이다.

본 연구에서는 이러한 배경을 토대로 24 개월의 미숙아로 출생한 영유아들을 정상언어발달과 언어발달지체로 집단을 나누어, 이들 이 15-18개월에 보였던 언어이전기 의사소통 행동에서 어떠한 차이 를 보였는지 살펴보고, 집단 간 차이를 보인 언어이전기 의사소통 행동을 통해 15-18개월에 언어발달지체를 보였던 영유아들 중 이 후 정상언어발달에 도달한 집단과 여전히 언어발달지체를 보이는 집단을 조기에 판별해줄 수 있는 요인이 무엇인지 밝히는 것을 목 적으로 하였다.

\section{연구 방법}

\section{연구대상}

본 연구의 대상자는 출생 시 체중이 $2.5 \mathrm{~kg}$ 미만이고, 재태기간 37 주 미만으로 출생한 47 명의 미숙아로 출생한 영유아들이었다. 모든 대상자는 부모 또는 의료 전문가로부터 발달적, 감각적, 기질 적, 신경학적 이상이 없으며, 이외 다른 동반장애가 없다고 보고되 었다. 중재효과를 통제하기 위해 언어재활을 받은 경험이 있거나 받 고 있는 영유아는 연구대상에서 제외하였다.

1 차 평가는 영유아의 생활월령이 15-18개월일 때 한국-베일리 영유아 발달검사II (K-BSID-II; Cho \& Park, 2006)와 영유아 언어 발달검사(SELSI; Kim et al., 2003)를 실시하였고, 언어이전기 의사 소통 행동 표본을 수집하였다. 그리고 약 6-8개월 후 영유아의 생 활월령이 24 개월이 되었을 때, 2차 평가로 SELSI를 실시하였다. 1 차 평가의 월령은 Wetherby, Cain, Yonclas, 그리고 Walker (1988)와 Cattani 등(2010)을 참고하여 언어 산출이 나타나지만 언어보다 언 어이전기 의사소통 행동을 더 자주 사용하며, 24 개월의 언어발달 을 가장 잘 예측해준다고 보고된 15-18개월로 정하였고, 2 차 평가 의 월령은 언어이전기 의사소통 행동이 감소하고, 언어 사용이 활 발해지기 시작하는 24 개월로 정하였다(Wetherby et al., 1988).

1 차 평가와 2 차 평가의 언어검사를 토대로 미숙아 집단을 세 집 단으로 분류하였다. SELSI (Kim, Kim, Yoon, \& Kim, 2003) 검사 결 과 1 차 평가와 2 차 평가 모두에서 '정상발달(+1 표준편차 이상)'에 속한 경우 ‘정상-정상’ 집단으로 명명하였으며, 10 명의 대상자가 포 함되었다. 1 차 평가에서 '약간 지체(-1 표준편차부터 -2 표준편차까 지)' 및 ‘언어발달 지체(-2 표준편차 이하)'에 속하였지만, 2 차 평가 에서 ‘정상발달’을 보인 경우 ‘지체-정상' 집단으로 명명하였으며, 18 명이었다. 마지막으로, 1 차와 2 차 평가 모두에서 ‘약간지체’ 및 ‘언 어발달지체’를 보인 경우 ‘지체-지체’로 명명하였으며, 19 명의 영유 아가 포함되었다. 2 차 평가 후 분류된 집단의 대상자 정보는 Table 1 
Table 1. Participants' characteristics

\begin{tabular}{|c|c|c|c|c|}
\hline & Typical-typical group ( $N=10$ ) & Delay-typical group ( $\mathrm{N}=18$ ) & Delay-delay group $(\mathrm{N}=19)$ & $F$ \\
\hline Chronological age (mo) & $23.80(.42)$ & $23.39(.85)$ & $23.37(.83)$ & .028 \\
\hline Birth weight (kg) & $1.66(.61)$ & $1.61(.71)$ & $1.66(.75)$ & .286 \\
\hline Gestational age (wk) & $30.90(4.43)$ & $31.11(3.83)$ & $31.89(3.63)$ & 1.174 \\
\hline \multicolumn{5}{|l|}{ SELSI } \\
\hline Receptive language age (mo) & 25.60 (2.41) & $24.28(2.35)$ & $21.95(3.64)$ & $5.723^{* *}$ \\
\hline Expressive language age (mo) & $24.70(2.06)$ & $22.61(1.85)$ & $16.68(2.87)$ & $47.878^{* * *}$ \\
\hline Combined language age (mo) & $25.30(2.11)$ & $23.56(1.89)$ & $19.53(2.74)$ & $24.736^{* *}$ \\
\hline \multicolumn{5}{|l|}{ K-BSID-II } \\
\hline Mental age (mo) & $24.00(3.02)$ & $22.38(2.80)$ & $23.13(3.16)$ & .809 \\
\hline Motor age (mo) & $25.63(3.02)$ & $23.38(2.19)$ & $23.63(3.22)$ & 1.625 \\
\hline
\end{tabular}

Values are presented as mean (SD).

SELSI= Sequenced of Language Scale for Infants (Kim, Kim, Yoon, \& Kim, 2003); K-BSID-II= Korean Bayley Scales of Infant Development II (Cho \& Park, 2006).

${ }^{* *} p<.01,{ }^{* * *} p<.001$

에 제시하였다.

세 집단의 기본 정보에 대한 집단 간 차이를 알아본 결과 세 집단 의 출생 시 체중, 재태기간, 생활월령, 인지 발달월령과 동작 발달월 령은 집단 간 유의한 차이가 없었다. 수용언어 월령 $\left(F_{(2,44)}=5.723\right.$, $p<.01)$, 표현언어 월령 $\left(F_{(2,44)}=47.878, p<.001\right)$, 전체언어 월령 $\left(F_{(2,44)}=\right.$ $24.736, p<.01)$ 에서는 집단 간 유의한 차이가 있었다.

\section{연구절차 및 검사도구}

본 연구의 모든 절차는 연구자가 속한 교내의 생명윤리위원회의 승인을 받았다. 연구는 1 차와 2 차 평가로 나누어 진행하였는데, 1 차 평가에서는 K-BSID-II (Cho \& Park, 2006), SELSI (Kim et al., 2003)와 언어이전기 의사소통 행동 표본을 수집하였고, 2 차 평가에서는 $\mathrm{K}-$ BSID-II (Cho \& Park, 2006)와SELSI (Kim et al., 2003)를 실시하였다.

1 차 평가에서 실시한 언어이전기 의사소통 행동 표본의 수집은 연구 대상자의 가정 내 독립된 공간에서 실시되었다. 영유아의 언 어이전기 의사소통 행동 표본을 수집하기 위해 어머니와 영유아의 1:1 자유놀이를 실시하였다. 행동 관찰을 위해 영유아와 어머니의 행동을 모두 관찰할 수 있으며 놀이에 방해를 주지 않는 곳에 캠코 더를 설치하였고, 약 15-25분 동안 영유아와 어머니의 상호작용을 관찰하였다. 의사소통 행동 수집에 앞서 모든 어머니에게 최대한 자연스러운 상호작용을 제공해 줄 것을 요구하는 상호작용 지침을 제공하였다. 모든 대상자들에게 동일하게 제공한 장난감은 인형, 소꿉놀이 도구(컵, 숟가락, 포크, 칼, 접시, 우유병, 후라이팬, 주걱, 뚜껑, 믹싱볼, 뒤집개, 주전자), 책 3권이었다. 이 도구들은 '의사소통 및 상징행동 척도(Communication and Symbolic Behavior Scale Developmental Profile, CSBS DP; Wetherby \& Prizant, 2002)'의 놀이절차에서 사용되는 도구로, 검사 대상자의 연령에 적합하고 많 은 선행연구들에서 보편적으로 사용되는 장난감들이었다. 모든 행
동 표본은 사전에 어머니의 동의를 얻어 디지털 캠코더(Samsung DCR-SX83)로 녹화하고 분석하였다.

\section{자료 분석}

영유아의 언어이전기 의사소통 행동을 평가하기 위해 수집된 어 머니와의 상호작용 자료의 도입부와 마무리 및 정리 시간을 제외하 고 10 분을 분석하였다. 분석된 의사소통 행동은 영유아가 어머니 에게 의도를 표현하기 위한 목적으로 사용한 행동만을 포함하였으 며, 생후 1년에서 2 세 사이 언어를 산출하기 이전의 영유아들이 습 득해야 한다고 보고된 언어이전기 의사소통 행동들이었다.(Bruner, 1981; Wetherby et al., 1988). 측정치는 의사소통 행동의 빈도와 유형수, 몸짓 빈도와 유형수, 발성 빈도, 자음 유형수였으며, Cho와 Lee (2010)를 참고하였다. 측정치에 대한 조작적 정의와 유형은 Appendix 1 에 제시하였다.

\section{신뢰도}

언어이전기 의사소통 행동에 대한 자료 분석의 신뢰도를 검증하 기 위해 연구자와 언어병리학을 전공하는 박사과정생 두 검사자 간 일치도를 구하였다. 연구자는 다른 검사자에게 연구절차와 자료 분석 기준을 설명한 후 함께 2 명의 자료로 분석을 연습하였다. 의견 이 불일치한 경우 분석 기준에 대한 조작적 정의와 영유아의 행동 을 함께 검토하여 최대한 일관된 분석을 할 수 있도록 연습하였다. 이후 '정상-정상', '지체-정상', '지체-지체' 세 집단 당 3명씩 임의로 선정하여 전체 수집된 자료의 약 $20 \%$ 인 9명을 독립적으로 분석하 였다. 최종적으로 두 검사자가 분석한 결과에 대하여 일치한 반응 의 수를 전체 반응 수로 나누어 100 을 곱한 일치도를 계산하였다. 그 결과 의사소통 행동의 빈도에 대한 신뢰도는 $93.7 \%$, 의사소통 행 동 유형수에 대한 신뢰도는 97\%, 몸짓 빈도에 대한 신뢰도는 93.6\%, 
HyoJoo Lee, et al. • Discriminating for Developmental Language Delay in Preterm Toddlers

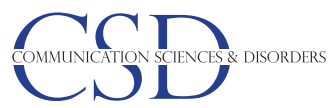

Table 2. Comparison of prelinguistic communicative factors by group

\begin{tabular}{|c|c|c|c|c|c|}
\hline & $\begin{array}{c}\text { Typical-typical (A) } \\
(\mathrm{n}=10)\end{array}$ & $\begin{array}{c}\text { Delay-typical (B) } \\
\quad(\mathrm{n}=18)\end{array}$ & $\begin{array}{l}\text { Delay-delay (C) } \\
\quad(\mathrm{n}=19)\end{array}$ & $F$ & Post-hoc \\
\hline Frequency of communicative behavior & $22.20(10.30)$ & $16.11(5.76)$ & $10.16(3.67)$ & $12.313^{* * *}$ & A vs. $B, A$ vs. $C, B$ vs. $A$ \\
\hline Type of communicative behavior & $3.90(1.10)$ & $3.89(1.18)$ & $3.11(1.15)$ & 2.642 & \\
\hline Frequency of gestures & $17.40(8.97)$ & $13.61(5.72)$ & $7.53(3.27)$ & $10.728^{* * *}$ & Avs. C, B vs. A \\
\hline Type of gestures & $3.70(1.42)$ & $3.44(1.25)$ & $2.84(1.34)$ & 1.674 & \\
\hline Frequency of vocalization & $10.10(6.62)$ & $7.00(5.63)$ & $4.84(3.95)$ & $3.308^{*}$ & Avs. C \\
\hline Type of consonants & $4.50(2.37)$ & $1.94(1.86)$ & $1.05(1.31)$ & $12.355^{* * *}$ & Avs. B, Avs. C \\
\hline
\end{tabular}

${ }^{*} p<.05,{ }^{* * *} p<.001$.

몸짓 유형수에 대한 신뢰도는 96.4\%, 발성 빈도에 대한 신뢰도는 $92.5 \%$, 자음 유형수에 대한 신뢰도는 98\%였다.

\section{통계분석}

언어이전기 의사소통 행동이 집단 간 어떠한 차이를 보이는지 알 아보기 위해 일원배치 분산분석(one-way ANOVA)을 실시하였고, 1 차 평가에 언어발달지체를 보였던 영유아들 중 2 차 평가에서 정 상수준에 도달한 영유아들과 지속적으로 지체를 보이는 영유아를 판별하는 1 차 언어이전기 의사소통 요인을 확인하기 위해 의사소통 행동의 하위항목을 독립변인으로 하고 두 집단을 종속변인으로 한 판별 분석(discriminant analysis)을 실시하였다.

\section{연구 결과}

\section{세 집단의 언어이전기 의사소통 행동 비교}

'정상-정상', '지체-정상', ‘지체-지체' 세 집단의 15-18개월의 언어 이전기 의사소통 행동에서 어떠한 차이를 보이는지 살펴보았으며, 결과는 Table 2 와 같다.

먼저, 의사소통 행동 빈도와 유형수, 몸짓 빈도와 몸짓의 유형수, 발성 빈도와 자음 유형수 모두에서 가장 높은 빈도를 보인 집단은 '정상-정상' 집단이었고, 다음으로 '지체-정상' 집단, 마지막으로 '지체-지체' 집단 순이었다. 세 집단의 빈도 차이가 통계적으로 유의 한지 알아보기 위해 실시한 분산분석 결과 의사소통 행동 빈도 $\left(F_{(2,44)}=12.313, p<.001\right)$, 몸짓 빈도 $\left(F_{(2,44)}=10.728, p<.001\right)$, 발성 빈도 $\left(F_{(2,44)}=3.308, p<.05\right)$, 자음 유형수 $\left(F_{(2,44)}=12.355, p<.001\right)$ 에 서 유의한 차이가 있었다.

언어이전기 의사소통 행동의 빈도가 어떤 집단에서 차이를 보였 는지 알아보기 위해 Tukey 사후분석을 실시한 결과, '정상-정상' 집 단과 '지체-정상' 집단 사이에서는 의사소통 행동 빈도와 자음 유 형수가 유의한 차이를 보였고, ‘정상-정상' 집단과 ‘지체-지체' 집단 사이에서는 의사소통 행동 빈도, 몸짓 빈도, 발성 빈도, 자음 유형
Table 3. Relative importance of prelinguistic communicative factors

\begin{tabular}{lc}
\hline Discriminative variables & Structure matrix \\
\hline Frequency of gestures & .808 \\
Frequency of communicative behavior & .762 \\
Types of consonants & .342 \\
Frequency of vocalization & .274 \\
\hline
\end{tabular}

수 모두 유의한 차이를 보였다. 마지막으로 '지체-정상' 집단과 '지 체-지체' 집단 사이에서는 의사소통 행동 빈도, 몸짓 빈도에서 유의 한차이를 보였다.

\section{언어이전기 의사소통 행동을 통한 언어발달지체와 정상언어발달 집단 판별 분석}

집단 간 유의한 차이를 보인 네 가지 요인을 독립변수로 하고, 집 단을 종속변수로 한 직접적 판별 분석을 실시한 결과, 도출된 함수 는 두 집단을 판별하기에 유의하였다(eigenvalue $=.699$, 정준상관 계수 $=.642, \mathrm{Wilks}$ 의 람다 $\left.=.588, \chi^{2}=17.499, p<.01\right)$. 구조행렬 (structure matrix)을 통해 초기 의도적 의사소통 행동의 상대적 중 요도를 살펴본 결과는 Table 3에 제시하였다.

각 사례의 판별점수와 그 사례가 갖는 예측변인에 대한 값의 상관 을 구한 중요도는 값이 클수록 변인들 사이에서 판별의 기여도가 높 은 것으로 해석할 수 있다. 일반적으로 구조행렬의 계수가 \pm .30 이 상의 값을 보일 때 그 중요도가 높다고 해석된다(Hair, Black, Babin, Anderson, \& Tatham, 2006). 본 연구의 결과에서는 '지체-정상'과 ‘지체-지체' 집단을 판별하는 데 있어서 몸짓 빈도, 의사소통 행동 빈도, 자음 유형수 순으로 높은 중요도를 보이는 것으로 나타났다.

본 연구에서 분류한 집단이 얼마나 정확하게 분류되었는지 살펴 본 결과 총 37 명 중 31 명이 정확히 분류되어 $83.8 \%$ 의 정확도를 보였 다. 정상수준에 도달한 집단에서는 총 18 명 중 14 명이, 지속적으로 언어발달지체를 보이는 집단에서는 총 19 명 중 17 명이 정확히 분류 되었다. 


\section{논의 및 결론}

본 연구는 미숙아 집단에서 언어발달지체와 정상언어발달 집단 을 판별해주는 요인을 밝히는것을 목적으로 실시되었다. 이를 위 해 1 차 평가와 2 차 평가의 언어검사 결과를 기초로 '정상-정상' '지 체-정상', ‘지체-지체' 세 집단으로 나누었다. 먼저, 세 집단 간 언어 이전기 의사소통 행동에서 어떠한 차이가 있는지 비교하고, 다음 으로 집단 간 차이를 보인 의사소통 행동을 통한 집단의 판별이 가 능한지 알아보았다.

\section{미숙아 집단의 15-18개월 언어이전기 의사소통 행동}

먼저 ‘정상-정상', ‘지체-정상', ‘지체-지체’ 집단 간 언어이전기 의 사소통 행동이 어떠한 차이가 있는지 알아보고자 하였다.

세 집단의 미숙아로 출생한 영유아들이 1 차 평가에서 보였던 의 사소통 행동의 빈도와 유형수, 몸짓 사용의 빈도와 유형수, 발성사 용의 빈도와 발성에 포함된 자음 유형수에서 집단 간 어떤 차이가 있는지 비교하였다. 그 결과 의사소통 행동의 빈도, 몸짓 빈도, 발성 빈도와 자음 유형수에서 집단 간 유의한 차이를 보였다. '정상-정 상' 집단은 '지체-정상' 집단에 비해 의사소통 행동의 빈도와 자음 유형수에서 유의하게 높은 수행능력을 보였고, '지체-지체' 집단에 비해 의사소통 행동 빈도, 몸짓 빈도, 발성 빈도, 자음 유형수에서 차이를 보였다. '지체-정상' 집단과 '지체-지체' 집단 사이에서는 의 사소통 행동 빈도와 몸짓 빈도에서 차이를 보였다.

'정상-정상' 집단과 '지체-정상' 집단 사이에는 의사소통 행동 빈 도와 자음 유형수에서 유의한 차이를 보였다. 본 연구에서 측정한 의사소통 행동의 빈도는 다른 측정치를 합한 전체 빈도이기 때문 에 두 집단 간 나타나는 의사소통 행동 빈도의 차이는 자음 유형수 의 차이로 인한 것일 수 있다. 자음 유형수는 영유아들이 초기에 습 득해서 사용하는 의사소통 수단 중 가장 늦은 시기에 발달하는 수 단이다(Oller, 2000; Wetherby et al., 1988). 본 연구의 '지체-정상' 집단의 영유아들은 초기에 비록 느린 발달을 보이지만, 더 어린 시 기에 출현하는 몸짓이나 발성과 같은 수단의 사용에서는 정상언어 발달 미숙아와차이를 보이지 않는 것으로 나타났다. 즉, 15-18개월 언어발달지체를 보이는 미숙아로 출생한 영유아들이 사용하는 자 음 유형수 외에 다른 수단의 사용이 빈번하다면, 이후 정상언어발 달수준에 도달할 잠재력을 가지고 있을 가능성이 더 커질 것이다.

‘정상-정상' 집단과 ‘지체-지체' 집단 사이에는 의사소통 행동 빈 도, 몸짓 빈도, 발성 빈도, 자음 유형수에서 유의한 차이를 보였다. 다수의 선행연구들에서 언어발달지체 영유아의 언어이전기 의사 소통 행동이 지체된 발달을 보이며(Cho \& Lee, 2010; Lee, 2011;
Paul \& Shiffer, 1991), 의사소통 행동은 이후 언어발달과 밀접한 관 련을 보인다고 보고되었다(Capirci, Iverson, Pizzuto, \& Volterra, 1996; Thal \& Tobias, 1992; Yoder \& Warren, 2001). 미숙아 출생 영 유아들은 만삭아 출생 영유아에 비해 지체된 의사소통 발달을 보 이며(De Groote et al., 2006; De Schuymer et al., 2011; Lee \& Lee, 2014; Olafsen et al., 2006; Oller et al., 1994; Van Noort-Van Der Spek et al., 2010), 또한 이후 언어발달과도 밀접한 관련을 보인다 (D’Odorico, Majorano, Fasolo, Salerni, \& Suttora, 2011; Sansavini et al., 2011; Smith \& Ulvund, 2003; Stolt, Lehtonen, Haataja, \& Lapinleimu, 2012; Stolt et al., 2014b; Suttora \& Salerni, 2012; Ulvund \& Smith, 1996). 본 연구 결과를 통해 미숙아 집단 내에서 언어발달이 지체된 경우 언어이전기 의사소통 행동의 빈도가 더 적으며, 이들 이 보인 적은 빈도의 언어이전기 의사소통 행동과 수단의 사용이 이후 언어 능력을 반영할수 있음을 시사하였다.

'지체-정상' 집단과 '지체-지체' 집단 사이에서는 의사소통 행동 빈도와 몸짓 빈도에서 유의한 차이를 보였다. 이는 15-18개월에 언 어발달지체를 보였던 미숙아 집단 내에서 24 개월까지 지속적으로 언어발달지체를 보이는 영유아들은 정상언어발달수준에 도달한 영유아들에 비해 상대적으로 더 적은 언어이전기 의사소통 행동의 빈도와 몸짓 빈도를 보인 것이다. 몸짓은 아직 구어를 습득하지 못 한 언어이전기 영유아들의 주요 의사소통 수단이다(Capone \& McGregor, 2004; Wetherby et al., 1988). 10-18개월 사이 정상발달 영유아들에게서 활발하게 사용되는 수단인 몸짓은 이후 언어발달 과 밀접한 관계를 보이며, 언어발달을 예측해주는 중요한 지표로서 많은 선행연구들에서 강조되어 왔다(Bates, 1979; Bates \& Dick, 2002; Calandrella \& Wilcox, 2000; Iverson \& Goldin-Meadow, 2005; Lee \& Lee, 2015; Özçalışkan \& Goldin-Meadow, 2005; Thal \& Tobias, 1992). 미숙아로 출생한 영유아의 몸짓 사용 능력을 살펴본 일 부 연구들에서도 미숙아로 출생한 영유아의 초기 몸짓 사용 능력 이 취약하다고 보고한 바 있다(Cattani et al., 2010; Sansavini et al., 2011; Stolt et al., 2014b). 본 연구에서도 선행연구들과 유사하게 15-18개월 사이에 의사소통 행동 수단으로 몸짓 사용 능력을 살펴 보았고, 이후 24 개월에 언어발달을 살펴보았다. 선행연구들에서는 이후 언어발달수준에 도달한 영유아들과 일부 지속적으로 지체를 보이는 영유아들이 한 집단에 포함되어 있었다는 데 본 연구와 차 이가 있었으나, 15 개월 경 언어발달지체를 보였던 미숙아로 출생한 영유아들의 초기 몸짓 사용 능력이 지체된 발달을 보인다는 것은 공통된 결과라고 할 수 있다.

언어발달지체 미숙아가 또래 정상언어발달 미숙아에 비해서도 지체된 발달을 보인 초기 몸짓 사용 능력은 이후 언어발달에 중요 
한 지표가 될 수 있을 것이다. Calandrella와 Wilcox (2000)는 언어 이전기 의사소통 행동의 빈도는 더 명확한 언어적 의사소통을 하 고자하는 영유아의 요구를 반영한다고 하였다. 즉, 구어보다 언어 이전기 의사소통 행동을 더 많이 사용하는 영유아들은 의사소통 상대자가 이해하기 어려운 수준의 의사소통 행동을 보일 것이다. 영유아는 몸짓, 발성과 같은 의미 전달이 다소 불명료한 언어이전 기 의사소통 행동을 사용함으로써 점점 증가되는 좌절을 경험하 는데, 이러한 어려움을 피하기 위해 스스로 더 구어적인 수단을 필 요로 할 것이며 이러한 동기 부여는 언어 습득을 촉진할 것이라고 제안하였다. 이를 통해 본 연구의 결과에서 '지체-정상' 집단의 언 어이전기 의사소통 수단의 사용 빈도가 비교적 높았던 것은 이들 이 의사소통 상대방에게 본인의 의사소통 의도를 더 정확하게 표 현하고자 하는 욕구에서 비롯된 것이며, 이러한 요구가 이후 언어 발달을 촉진시킨 것으로 해석할 수 있다. 본 연구의 '지체-지체' 집 단과 ‘지체-정상' 집단에서 나타난 유의한 차이를 통해 언어이전기 의사소통 행동을 통한 두 집단의 조기 판별의 가능성을 시사하였다.

\section{언어이전기 의사소통 행동을 통한 언어발달지체와 정상언어발달 집단 판별}

'지체-정상' 집단과 '지체-지체'집단 간 차이를 보였던 의사소통 행동 빈도, 몸짓 빈도, 발성 빈도, 자음 유형수를 통한 집단의 판별 이 가능한지 알아보기 위해 판별분석을 실시하였다.

1 차 평가에서 언어발달지체를 보였던 미숙아 집단 내에서 2 차 평 가에서 정상언어발달에 도달한 집단과 언어발달지체를 보인 집단 의 판별 분석 결과 도출된 함수는 통계적으로 유의하였으며, 분류 정확도는 $83.8 \%$ 의 높은 정확도를 보였다. 따라서 15-18개월에 보인 언어이전기 의사소통 행동이 24 개월의 정상언어발달 집단과 언어 발달지체 집단을 조기에 판별해줄 수 있는 것으로 나타났다. 특히 ‘지체-정상' 집단과 ‘지체-지체' 집단의 판별에 있어서 몸짓 빈도, 언 어이전기 의사소통 행동의 빈도 및 자음 유형수가 상대적으로 높 은 중요도를 보였다.

몸짓 사용의 빈도는 ‘지체-정상' 집단과 ‘지체-지체’ 집단 사이에 서 유의한 차이를 보였을 뿐만 아니라, 두 집단을 조기에 판별해줄 수 있는 가장 중요도 높은 요인이었다. Bates와 Dick (2002)은 15개 월 전후 영유아들에게서 활발하게 사용되는 언어이전기 의사소통 수단 중 하나로 몸짓을 꼽았다. 구어를 활발하게 사용하기 이전의 영유아들은 주로 의사소통 수단으로써 몸짓을 사용하며, 24 개월 을 전후로 몸짓의 빈도는 급감하고 구어 산출이 더 활발해진다 (Hong \& Kim, 2001; Wetherby et al., 1989). 본 연구에서 지속적으 로 언어발달지체를 보이는 집단의 영유아들은 상대적으로 매우 적
은 빈도의 몸짓을 사용하였다. 따라서 이들의 지체된 몸짓 사용 능 력이 이후 언어발달 정도를 반영하는 중요한 요인 중 하나인 것으 로 해석할 수 있다(Bates \& Dick, 2002).

미숙아로 출생한 영유아의 언어발달 예측요인을 살펴본 다수의 연구들에서는 의사소통 행동 빈도, 몸짓과 자음수가 중요한 요인 인 것으로 반복적으로 보고되어 왔다(De Schuymer et al., 2011; Sansavini et al., 2011; Smith \& Ulvund, 2003; Suttora \& Salerni, 2012; Ulvund \& Smith, 1996). Ulvund와 Smith (1996)는 13개월 영 유아의 의사소통 행동이 2 세 언어발달을 예측해줄 수 있다 하였고, 이러한 예측력은 3 세와 5세까지 유지되었다. Smith와 Ulvund (2003) 의 연구에서는 13 개월 의사소통 행동이 8 세까지 영향을 미치는 것 으로 나타났다. Stolt 등(2014b)과 Cattani 등(2010)은 초기 몸짓 사 용 능력이 이후 언어발달을 예측해줄 수 있으며, 특히 Cattani 등 (2010)은 24개월의 언어 능력을 가장 잘 예측해줄 수 있는 시점은 15 개월이라고 제안하였다. 12,18 개월의 음절성 발성의 산출 능력 을 살펴본 D'Odorico 등(2011) 또한 18 개월 영유아의 자음 산출 능 력이 24 개월의 어휘발달과 관련을 보인다고 하였다. 본 연구의 결 과를 통해 24 개월의 언어발달 정도를 판별해주는 가장 중요도 높 은 15-18개월의 언어이전기 의사소통 행동 빈도와 몸짓 빈도 및 자 음 유형수는 이후 언어발달과 밀접한 관련을 보일 뿐만 아니라 초 기에 두 집단을 구별해줄 수 있는 요인인 것으로 나타났다.

본 연구의 결과를 종합하면, 세 집단 간 15-18개월에 측정한 의 사소통 행동 빈도, 몸짓 빈도, 발성 빈도 및 자음 유형수에서 집단 간 유의한 차이를 보였다. 언어발달지체 미숙아로 출생한 영유아 들이 1 차 평가의 언어이전기 의사소통 행동에서도 정상발달 미숙 아로 출생한 영유아보다 느린 발달을 보인다는 본 연구의 결과를 통해 언어이전기 의사소통 행동의 사용 능력이 이후 언어발달의 중 요한 지표가 될 수 있다는 것을 확인할 수 있었다. 15-18개월 사이 에 미숙아로 출생한 영유아들이 보인 언어이전기 의사소통 행동요 인은 24 개월의 언어발달지체 정도를 조기에 판별하기에 적합한 것 으로 나타났다. 특히, 15-18개월 사이 언어발달지체를 보이는 미숙 아로 출생한 영유아들의 언어이전기 의사소통 행동의 빈도, 몸짓 사용의 빈도와 산출 가능한 자음 유형수는 24 개월의 언어발달 정 도를 예측하데 유용한 정보를 제공해줄 것이다.

Billeaud (2003)는 미숙아 출생과 같이 높은 발생률을 보이지만 쉽게 눈에 띄지 않는 장애들에 대하여 '다른 발달 영역에 부정적인 영향을 미칠 수 있는 문제와 문제가 가지고 있는 잠재력이 가진 파 급력을 밝히는 것에 대한 노력'이 필요하다고 언급하였다. 본 연구 에서는 이후 언어발달지체를 보일 수 있는 미숙아로 출생한 영유아 의 '잠재력'의 발견에 대한 기초를 마련했다는 점에서 의의가 있다. 
후속연구에 대한 제언으로 정상언어발달수준에 도달한 집단과 지 속적으로 언어발달지체를 보이는 미숙아로 출생한 영유아 집단을 유아기 아동기를 거쳐 학령기까지의 언어발달이 어떠한 특성을 보 이는지 종단적으로 추적하는 연구가 필요할 것이다. 마지막으로, 본 연구에서 미숙아로 출생한 영유아 집단 내에서 이후 정상언어 발달에 도달하는 집단과 언어발달지체를 보이는 집단을 더 이른 시 기에 판별하고자 했던 목적은 조기중재와도 관련이 있었다. 본 연 구의 판별 분석 결과에서 밝혀진 몸짓, 발성, 자음 유형수와같은 언 어이전기 의사소통 행동을 목표로 한 중재를 실시했을 때, 어떠한 효과가 있는지 중재효과를 검증하는 연구가 진행되어야 할 것이다.

\section{REFERENCES}

Aram, D. M., Hack, M., Hawkins, S., Weissman, B. M., \& Borawski-Clark, E. (1991). Very-low-birthweight children and speech and language development. Journal of Speech, Language, and Hearing Research, 34, 1169-1179.

Bates, E. (1979). The emergence of symbols: cognition and communication in infancy. New York: Academic Press.

Bates, E., \& Dick, F. (2002). Language, gesture, and the developing brain. Developmental Psychobiology, 40, 293-310.

Billeaud, F. P. (2003). Communication disorders in infants and toddlers: assessment and intervention (3rd ed.). St. Louis, MO: Butterworth-Heinemann.

Bornstein, M. H., \& Haynes, O. M. (1998). Vocabulary competence in early childhood: measurement, latent construct, and predictive validity. Child Development, 69, 654-671.

Bruner, J. (1981). The social context of language acquisition. Language \& Communication, 1, 155-178.

Calandrella, A. M., \& Wilcox, M. J. (2000). Predicting language outcomes for young prelinguistic children with developmental delay. Journal of Speech, Language, and Hearing Research, 43, 1061-1071.

Capirci, O., Iverson, J. M., Pizzuto, E., \& Volterra, V. (1996). Gestures and words during the transition to two-word speech. Journal of Child Language, $23,645-673$.

Capone, N. C., \& McGregor, K. K. (2004). Gesture development: a review for clinical and research practices. Journal of Speech, Language, and Hearing Research, 47, 173-186.

Cattani, A., Bonifacio, S., Fertz, M., Iverson, J. M., Zocconi, E., \& Caselli, M. C. (2010). Communicative and linguistic development in preterm children: a longitudinal study from 12 to 24 months. International Journal of Language \& Communication Disorders, 45, 162-173.
Cho, B. H., \& Park, H. W. (2006). Korean-Bayley Scales of Infant Development II (K-BSID-II). Seoul: Mindpress.

Cho, M. R., \& Lee, Y. K. (2010). Communicative behaviors of toddlers with or without language delay. Korean Journal of Early Childhood Special Education, 10, 31-46.

D’Odorico, L., Majorano, M., Fasolo, M., Salerni, N., \& Suttora, C. (2011). Characteristics of phonological development as a risk factor for language development in Italian-speaking pre-term children: a longitudinal study. Clinical Linguistics \& Phonetics, 25, 53-65.

De Groote, I., Roeyers, H., \& Warreyn, P. (2006). Social-communicative abilities in young high-risk preterm children. Journal of Developmental and Physical Disabilities, 18, 183-200.

De Schuymer, L., De Groote, I., Beyers, W., Striano, T., \& Roeyers, H. (2011). Preverbal skills as mediators for language outcome in preterm and full term children. Early Human Development, 87, 265-272.

Foster-Cohen, S., Edgin, J. O., Champion, P. R., \& Woodward, L. J. (2007). Early delayed language development in very preterm infants: evidence from the MacArthur-Bates CDI. Journal of Child Language, 34, 655-675.

Hair, J. F., Black, W. C., Babin, B. J., Anderson, R. E., \& Tatham, R. L. (2006). Multivariate data analysis (6th ed.). Upper Saddle River, NJ: Pearson.

Hong, G. H., \& Kim, Y. T. (2001). A longitudinal study of the acquisition of communicative intentions. Korean Journal of Communication Disorders, 6, 17-39.

Hong, K. (2004). A longitudinal study of predictors for expressive vocabulary development of the late-talkers (Doctoral dissertation). Ewha Womans University, Seoul, Korea.

Iverson, J. M., \& Goldin-Meadow, S. (2005). Gesture paves the way for language development. Psychological Science, 16, 367-371.

Jeon, J. (2014). Early social communication factors discriminating autism spectrum disorder from developmental language delay (Doctoral dissertation). Hallym University, Chunchoen, Korea.

Jeon, J., \& Lee, Y. (2015). Discriminative items of early social communication between autism spectrum disorder and developmental language delay under the age of three. Asia Pacific Regional International Meeting for Autism Research, Shanghai, China.

Jeon, J., Lee, H., \& Lee, Y. (2013). Comparison of language and social communication abilities of toddlers who are at risk of autism spectrum disorders and developmental language delay. Communication Sciences \& Disorders, 18, 349-359.

Kim, Y. T., Kim, K. H., Yoon, H. R., \& Kim, H. S. (2003). Sequenced Language Scale for Infants (SELSI). Seoul: Special Education Publishing. 
Koldewijn, K., Wolf, M. J., van Wassenaer, A., Meijssen, D., van Sonderen, L., van Baar, A., ... \& Kok, J. (2009). The Infant Behavioral Assessment and Intervention Program for very low birth weight infants at 6 months corrected age. Journal of Pediatrics, 154, 33-38.

Lee, H., \& Lee Y. (2013). Literature review of premature child's communication and language development. Korean Journal of Early Childhood Special Education, 13, 327-346.

Lee, H., \& Lee, Y. (2014). Characteristics of social communication behavior in premature toddlers. Korean Journal of Early Childhood Special Education, $14,105-120$.

Lee, Y. (2011). The relationships among language, communicative abilities and motor, cognitive, and socio-emotional development in toddlers with language delays. Korean Journal of Communication Disorders, 16, 1-12.

Lee, Y., \& Lee, H. (2015). Communicative gestures in toddlers with developmental language delay and their relations to language development. Communication Sciences \& Disorders, 20, 255-265.

Lee, Y., \& Lee, H. (2016). Prevalence of developmental language delay among toddlers born as preterm. Communication Sciences \& Disorders, 21, 60-68.

Marston, L., Peacock, J. L., Calvert, S. A., Greenough, A., \& Marlow, N. (2007). Factors affecting vocabulary acquisition at age 2 in children born between 23 and 28 weeks' gestation. Developmental Medicine \& Child Neurology, 49, 591-596.

Moeller, M. P. (2000). Early intervention and language development in children who are deaf and hard of hearing. Pediatrics, 106, e43.

Olafsen, K. S., Rønning, J. A., Kaaresen, P. I., Ulvund, S. E., Handegård, B. H., \& Dahl, L. B. (2006). Joint attention in term and preterm infants at 12 months corrected age: the significance of gender and intervention based on a randomized controlled trial. Infant Behavior and Development, 29, 554-563.

Oller, D. K. (2000). The emergence of the speech capacity. Mahwah, NJ: Lawrence Erlbaum Associates.

Oller, D. K., Eilers, R. E., Steffens, M. L., Lynch, M. P., \& Urbano, R. (1994). Speech-like vocalizations in infancy: an evaluation of potential risk factors. Journal of Child Language, 21, 33-58.

Özçalışkan, Ş., \& Goldin-Meadow, S. (2005). Gesture is at the cutting edge of early language development. Cognition, 96, B101-B113.

Paul, R., \& Shiffer, M. E. (1991). Communicative initiations in normal and late-talking toddlers. Applied Psycholinguistics, 12, 419-431.

Rescorla, L., \& Schwartz, E. (1990). Outcome of toddlers with specific expressive language delay. Applied Psycholinguistics, 11, 393-407.

Rossetti, L. M. (2001). Communication intervention: birth to three. San Diego,
CA: Singular Thomson Learning.

Saavalainen, P., Luoma, L., Bowler, D., Timonen, T., Määttä, S., Laukkanen, E., \& Herrgård, E. (2006). Naming skills of children born preterm in comparison with their term peers at the ages of 9 and 16 years. Developmental Medicine \& Child Neurology, 48, 28-32.

Sansavini, A., Guarini, A., Savini, S., Broccoli, S., Justice, L., Alessandroni, R., ... \& Faldella, G. (2011). Longitudinal trajectories of gestural and linguistic abilities in very preterm infants in the second year of life. Neuropsychologia, 49, 3677-3688.

Schults, A., Tulviste, T., \& Haan, E. (2013). Early vocabulary in full term and preterm Estonian children. Early Human Development, 89, 721-726.

Smith, L., \& Ulvund, S. E. (2003). The role of joint attention in later development among preterm children: linkages between early and middle childhood. Social Development, 12, 222-234.

Snow, C. W., \& McGaha, C. G. (2003). Infant development (3rd ed.). Upper Saddle River, NJ: Prentice Hall.

Soraya, M., Mahmoodi-Bakhtiari, B., Badiee, Z., Kazemi, Y., \& Soleimani, B. (2012). The size of expressive lexicon in prematurely born children lowbirth-weight with full-term 18 to 36 month's children: a comparative study. Journal of Neuroscience and Behavioural Health, 4, 33-36.

Stolt, S., Korja, R., Matomäki, J., Lapinleimu, H., Haataja, L., \& Lehtonen, L. (2014a). Early relations between language development and the quality of mother-child interaction in very-low-birth-weight children. Early Human Development, 90, 219-225.

Stolt, S., Lehtonen, L., Haataja, L., \& Lapinleimu, H. (2012). Development and predictive value of early vocalizations in very-low-birth-weight children: a longitudinal study. Clinical Linguistics \& Phonetics, 26, 414-427.

Stolt, S., Mäkilä, A. M., Matomäki, J., Lehtonen, L., Lapinleimu, H., \& Haataja, L. (2014b). The development and predictive value of gestures in verylow-birth-weight children: a longitudinal study. International Journal of Speech-Language Pathology, 16, 121-131.

Suttora, C., \& Salerni, N. (2012). Gestural development and its relation to language acquisition in very preterm children. Infant Behavior and Development, 35, 429-438.

Thal, D. J., \& Tobias, S. (1992). Communicative gestures in children with delayed onset of oral expressive vocabulary. Journal of Speech, Language, and Hearing Research, 35, 1281-1289.

Ulvund, S. E., \& Smith, L. (1996). The predictive validity of nonverbal communicative skills in infants with perinatal hazards. Infant Behavior and Development, 19, 441-449. 
Van Noort-Van Der Spek, I. L., Franken, M. C. J., Wieringa, M. H., \& Weisglas-Kuperus, N. (2010). Phonological development in very-low-birthweight children: an exploratory study. Developmental Medicine \& Child Neurology, 52, 541-546.

Vohr, B. (2014). Speech and language outcomes of very preterm infants. Seminars in Fetal and Neonatal Medicine, 19, 78-83.

Wetherby, A. M., \& Prizant, B. M. (2002). CSBS DP manual: communication and symbolic behavior scales: developmental profile. Baltimore, MD: Paul H. Brookers Publishing.

Wetherby, A. M., Cain, D. H., Yonclas, D. G., \& Walker, V. G. (1988). Analysis of intentional communication of normal children from the prelinguistic to the multiword stage. Journal of Speech, Language, and Hearing Research, $31,240-252$.

Wetherby, A. M., Yonclas, D. G., \& Bryan, A. A. (1989). Communicative profiles of preschool children with handicaps: implications for early identification. Journal of Speech and Hearing Disorders, 54, 148-158.

Yoder, P. J., \& Warren, S. F. (2001). Relative treatment effects of two prelinguistic communication interventions on language development in toddlers with developmental delays vary by maternal characteristics. Journal of Speech, Language, and Hearing Research, 44, 224-237. 
HyoJoo Lee, et al. • Discriminating for Developmental Language Delay in Preterm Toddlers

Appendix 1. 언어이전기 의사소통 행동의 조작적 정의와 유형

언어이전기 의사소통 행동

$$
\text { 조작적 정의 및 유형 }
$$

의사소통 행동 빈도

영유아가 상대방에게 의사소통 의도를 표현한 빈도의 총 수

의사소통 행동 유형수

9가지 의사소통 행동 유형 중 영유아가 사용한 유형의 수로, 사물요구하기, 사물 거부하기, 행동 요구하기, 행동 거부하기, 인사하기, 부르기, 보여주기, 언급하기, 질문하기 포함

몸짓 빈도

영유아가 의사소통 의도를 표현하기 위해 사용한 몸짓의 빈도

몸짓 유형수

8개의 몸짓 유형 중 영유아가 사용한 유형의 수로, 가리키기, 주기, 보여주기, 손 내밀기, 손 흔들기, 손 가로젓기, 고개 가로젓기, 끄덕이기 포함

발성 빈도

영유아가 의사소통 의도를 표현하기 위해 사용한 전사 가능한 말소리로, 모음과 자음 위주 발성, 모음 유사소리, 자음포함 음절 포함

자음 유형수

영유아가 산출한 말소리에 포함된 자음의 총 수 


\section{국문초록}

\section{미숙아 집단의 언어발달지체를 판별하는 언어이전 의사소통 행동 요인}

이효주 $\cdot$ 이윤경

'한림대학교 대학원 언어병리청각학과, ${ }^{2}$ 한림대학교 언어청각학부

배경 및 목적: 언어이전기 의사소통 행동은 언어발달지체와 정상언어발달을 판별하는 주요한 요인이다. 본 연구의 목적은 2 세 미숙아 집단에서 언어발달지체와 정상언어발달을 판별하는 가장 중요도 높은 요인이 무엇인지 밝히고자 하였다. 방법: 대상자는 미숙아로 출 생한 영유아 47 명이었다. 대상자들은 언어검사 결과에 따라 '정상-정상'집단, '지체-정상'집단, '지체-지체'집단으로 분류되었다. 양육자 와의 자유놀이 상황에서 영유아의 의사소통 행동을 수집하였고, 수집된 의사소통 행동 표본에서 의사소통 행동 빈도와 유형수, 몸짓 빈도와 유형수, 발성 빈도와 자음 유형수를 측정하였다. 결과: '지체-지체'집단은 유의하게 낮은 의사소통 행동, 몸짓, 발성의 빈도를 보 였고, 유의하게 적은 수의 자음을 산출하였다. 판별분석 결과 몸짓 빈도, 의사소통 행동 빈도, 자음 유형수가 미숙아 집단 내 '지체-정 상'과 ‘지체-지체'집단을 판별하는데 가장 중요도 높은 요인이었다. 논의 및 결론: 연구결과에 따라 미숙아 집단의 언어발달지체와 정 상언어발달을 판별해주는 언어이전기 의사소통 행동에 대하여 논의하였다.

핵심어: 미숙아, 언어이전기 의사소통 행동, 판별분석

본 연구는 2014년 정부(교육부)의 재원으로 한국연구재단의 지원을 받아수행되었음(NRF-2014S1A5A2A01015713).

이 논문은 제 1 저자의 박사학위논문(2016)의 일부를 발췌한 것임.

\section{참고문헌}

김영태, 김경희, 윤혜련, 김화수(2003). 영유아 언어발달 검사(SELSI). 서울: 도서출판 특수교육.

이윤경(2011). 언어발달지체 영유아의 언어 및 의사소통 능력과 인지, 운동 및 사회성 발달과의 관계. 언어청각장애연구, 16, 1-12.

이윤경, 이효주(2015). 언어발달지체 영아의 의사소통적 제스처 특성과 언어발달과의 관계. 언어청각장애연구, 20, 255-265.

이윤경, 이효주(2016). 미숙아 출생 영유아의 언어발달지체 출현율. 언어청각장애연구, 21, 60-68.

이효주, 이윤경(2013). 미숙아출생 영유아의 언어 및 의사소통 발달 연구 동향. 유아특수교육연구, 13, 327-346.

이효주, 이윤경(2014). 미숙아 출생 영유아의 사회적 의사소통 행동 특성. 유아특수교육연구, 14, 105-120.

전진아(2014). 자폐범주성장애 위험군과 언어발달지체 영유아의 판별요인 연구. 한림대학교대학원 박사학위논문.

전진아, 이효주, 이윤경(2013). 자폐범주성장애 의심 영유아와 언어발달지체 영유아의 언어 및 사회적 의사소통 능력 비교. 언어청각장애연구, 18 ,

349-359.

조미라, 이윤경(2010). 언어발달지체 유아와 일반 유아의 의사소통 행동 비교. 유아특수교육연구, 10,31-46.

조복희, 박혜원(2006). 한국-베일리 영유아발달검사(K-BSID-II). 서울: 마인드프레스.

홍경훈(2004) ' '말늦은아동(late-talker)'의 표현어휘발달 예측요인에 대한 종단연구. 이화여자대학교대학원 박사학위논문.

홍경훈, 김영태(2001). 아동의 의사소통의도 습득에 대한 종단연구. 언어청각장애연구, 6, 17-39. 